\author{
Olga Jagnicka \\ ๑ https://orcid.org/0000-0002-0262-8817 \\ University of Lodz \\ olgajagnicka@gmail.com
}

\title{
CONTEMPORARY ART AND ITS BOUNDARIES: PERMEATION OR PERVASION?
}

\begin{abstract}
The article discusses the significance of the ethical aspects and limits in contemporary art. The text refers to the collection of works that were created based on torturing or killing animals. Those particular works have been considered as breaking ethical limits, evoked indignation and numerous protests of the public. The paper touches the issue of consequences resulting from such reactions, and the scandal that was born around the referred works. This forces me to pose a question not only on the reasonable limits of works of art and the importance of aesthetics, but also on the definition of the term 'art'. The word 'art', having been applied to a number of redefinitions, makes it difficult or even impossible to set up clear rules. My analysis is not only attempted at answering questions on the limits of the contemporary art, but also on the justification of the term 'art' itself in relation to today's artistic creations.
\end{abstract}

Keywords: boundaries of art, contemporary art, ethics, definition of art, animals in art, a work of art.

Does art have any boundaries? Although this question might seem nad've, it actually points to a complex problem which contemporary art faces, that is, the lack of a definition which would aptly describe its condition. Just when does the work of an artist stop being seen as art? What are the boundaries of art? Does an artwork lose its ethical dimension once it starts provoking the audience? Just what is the extent of what an artist may or may not do in creating their work?

The ethical layer in art is an extremely important element, which on the one hand may seem to be something limiting, and on the other hand it is a kind of 'brake' thanks to which the field of art may remain within broad limits. As Dariusz Gzyra rightly observes, "The ability of homo sapiens to deliberate on evil and good, to experience moral emotions and, above all, to modi- 
fy their own behavior on the basis of these emotions, achieved by homo sapiens through evolution, carries a huge potential for freedom. Paradoxically, freedom through limitation, abandonment of opportunities and tendencies that harm others. (...) Ethics, therefore, despite the fact that it limits, does not enslave. On the contrary, by adding a new dimension to life, it gives space to freedom."

However, the establishment of borders is extremely difficult. There is a fear that creativity will disappear when borders are set. It is also obvious that: "You can be the creator of a work of art that hurts and annihilates, whose matter is the effect of harm or even suffering itself. (...) in the unquestionable area of art, in its terminologically safe middle, we have countless examples of the involvement of artists and works of art in someone's harm". ${ }^{2}$ The intention and the work of art that arises from it is ethically problematic. Art is an area where, according to some people, one can try with impunity the human tendency to evil and violence; an area where one can suspend ethical norms and experiment with instincts. Very soon you can fall into the trap of thinking that in art everything is slow.

Art serves many functions. It can show beauty, discuss important subjects, provoke contemplation of compelling issues. If an artist aims to address an issue through the killing or torturing of animals, can their activity be artistic? What if an animal is reduced to being a material from which an exhibit is made? Is the ethical dimension of artistic activity necessary for a work to be an artwork?

Of course, art is free, but does it mean that it has no borders? Art actively participates in animal studies discourse, co-creating it, and at the same time demands comment, interpretation and understanding in a broader cultural, socio-political and ethical context. ${ }^{3}$ Animals have been the subject of art since it began. They are present in prehistoric paintings on cave walls, as well as in genre painting, portraits and ornaments. Their function was always dramaturgical, emblematic-symbolic, decorative; they stood as motives, material, metaphor. Animals rarely represented themselves. They served and still serve as a media of meaning, representatives of human desires, fears, drives; as objects projecting all kinds of human matters. Singular animals were seen as the representatives of a species or symbols of nature. The individuality of animals and their rights went unnoticed or were negated. Sometimes an animal was killed just so a human could draw it, mold it into a sculpture or use parts of its body in order to produce painting materials, or animals were just used to illustrate someone's

1 D. Gzyra, Sztuka wspótczesna wobec etyki i dyskursu praw zwierząt, „Magazyn Sztuki” 2014, no 5 , p. 21.

Ibid., p. 19.

3 D. Gzyra, D. Łagodzka, Uczestniczac w zwrocie zwierzęcym. Sztuka wobec zwierząt, „Magazyn Sztuki” 2014, no 5, p. 6. 
ideas-as is the case today. More or less since the infamous event of Joseph Beuys and the coyote (1970s), there has been a significant change in the way of thinking about human's relationship with animals, a type of animal turn in which human became more interested in animal. Artists head towards an antispeciesist treatment of animals. They shape and react to social changes. Many artworks make an animal its 'I', its subject, which relates to the development of animal rights movements or academic animal studies. During the performance I Like America and America Likes Me (Rene Block Gallery, New York 1974), Beuys spent three days in an enclosed room alone with a wild coyote, separated from the audience by metal netting The artist treated the animal as an equal partner who he did not attempt to exercise control over in any way.

Contemporary artistic practice is full of examples where live animals take part in creating an artwork. Each such project triggers the question of the animal's role in the venture because there are still many examples which raise doubts about whether such treatment of animals is ethical. Steve Baker, the author of many publications on the ethical and artistic aspects of depicting animals in contemporary art, cautions against an overly nad've approach to today's treatment of animals. ${ }^{4}$ The shift away from the anthropocentrism of traditional art did not necessarily guarantee animals fair treatment. How far can using animals as a medium go before art becomes pseudo-art? Some cases which are generally considered to be art challenge the notion that art can neglect its ethical dimension. These are works created through causing animals pain, torturing or even killing them.

During an event accompanying the Europe Theatre Prize (Premio Europa per il Teatro) in 2009 in the city of Wrocław, Poland, the playwright Rodrigo García presented the performance Incident: Kill to Eat (Accidens: matar para comer). García is known for his strategies of provocation, forcing the audience to challenge and negate dominating ideas.

In the logic of classification, Rodrigo García is labelled as a 'brutal surrealist', 'provocateur', 'terrorist' and 'iconoclast'. Scandal - which he himself weaves into his projects - is an inseparable companion to many of his actions. His strategy lies in showing that the contemporary world is the biggest scandal; he uncovers its hypocrisy and brutal logic which reduces everything to a product. Hence, a creative act must take such practices into consideration. To surprise the audience and catch them in a trap of what escapes possession and consumption one must act without anesthesia. ${ }^{5}$

4 S. Baker, The animal in contemporary art, http://www.fathom.com/feature/122562/index. html (08.03.2019)

5 http://2014.malta-festival.pl/en/program/idiom/rodrigo-garciiteatr-bez-znieczulenia (07.03.2019) 
The thirty-minute performance Incident: Kill to Eat begins with a scene in which the actor fishes a lobster from a water-tank and then hangs it a meter and a half from the ground. A microphone is attached to the crustacean to register its heart rate. In absolute silence the actor smokes a cigar and observes the animal, then stabs it with a pin. The animal reacts, it is alert, animated, moving, but with every minute it becomes more and more lifeless. The audience hears its heartbeat, at first lively, then getting slower and quieter. The man takes the dead lobster off the line and under a meat chopper. He adds spices, drizzles some olive oil on it. The actor pours himself a glass of white wine and, when the lobster is cooked, eats it. García then announces that the performance is over.

Another of his plays staged in Wrocław was Cover Mickey Mouse in my ashes (Arrojad mis cenizas sobre Mickey). This time the actor threw Syrian hamsters, one by one, into an aquarium. These semi-desert rodents cannot swim. Only when they started drowning after long moments of trying to keep above the surface, did the actor fish them out with a landing net. An activist from a Polish animal rights organization (pol. Straż dla zwierzat w Polsce) came on stage when the second of five hamsters was being tormented and put an end to the performance by taking all the hamsters with her. Both plays were supposed to demonstrate that killing animals is a part of most people's daily lives; the performance was to convince the audience to stop eating meat. Concerning animals, García says that "they are a very important element of his theatre. The animal is a source of fear: when we observe animals, we can see the many traits and behaviors we ourselves possess. We cannot escape the animal part of human nature. Animals remind us of it. Besides, I like having animals on stage because they are unpredictable. You never know what it's going to do, and that breeds tension. That breed dramatism" ${ }^{6}$ The artist was accused of going too far both conventionally and legally. The court, however, ruled that the way the lobster was killed during García's play is far more humanitarian than the way these animals are killed in restaurants. Therefore, the playwright is not tormenting lobsters, but simply unmasking what happens to them on a regular basis. This death ritual becomes unbearable when we realize that we partake in it. García wants to point out this hypocrisy. Yet will torturing a live animal onstage really convince people to leave meat out of their diet? Is killing an animal before an audience of 300 really art? Is the artist's set goal achieved in any way?

Hermann Nitsch is yet another artist whose artistic activity abounded in scandal, so much as to cause police intervention more than once. Nitsch was one of the infamous Viennese Activists whose work was full of blood and gore, violence and torture. His Orgiastic Mystery Theater (Orgies Mysterien Theater)

6 https://www.dwutygodnik.com/artykul/5249-nie-wierze-w-polityczna-moc-teatru.html (07.03.2019) 
gained him wide recognition. It involved staging nearly 100 artistic events between 1962 and 1998. The first of these performances had Nitsch and his collaborators wall themselves in a Viennese basement where they crucified a lamb before a sheet of white cloth. The artist believed that such performances can liberate fears and control from the subconscious. During various events he killed animals, mainly pigs and sheep which were sick or set for slaughter, chopped them into pieces, hung them up, stomped on them and spilled buckets of blood. He covered himself, his collaborators and the audience with the dead meat. These performances were to create relics which mimic the Catholic rite: bloodstained sheets, monstrances, and crosses. Such means of expression can offend the most innermost feelings, not just one's religious sensitivity. Nitsch explains that we can only accept the world with all its extremity through experiencing the ecstasy and cruelty of death, which is made available through scenes of murdering animals. He wants to restore human's lost carnal nature using raw meat and bloodstained tools-to reinstate humans in the bosom of nature so that they can reconcile with themselves anew. ${ }^{7}$

The much debated 1993 graduate piece by Katarzyna Kozyra, Pyramid of Animals, provoked questions concerning the moral aspect of art and the barriers of an artist's freedom of expression. Kozyra created an object which consisted of four taxidermy animals set upon each other: a horse, a dog, a cat and a rooster (two of these animals were killed specifically for this project). The screening of a film which showed the slaughter of a horse accompanied the sculpture at the exhibition. Controversy broke out, and the limits of artistic practice were questioned once more. ${ }^{8}$ It was the scandal that surrounded the event through which Kozyra wanted to demonstrate the double standards which rendered a sculpture of stuffed animals a controversy, while the daily mass murder of animals was hardly questioned.

Another known example is that of Guillermo Vargas who had a haggard dog tied on a line in an exhibition room. This dog was to serve as an exhibit. Nobody protested. According to some sources, the dog died on the second day of the exhibition; according to others, it managed to run away. The issue was taken up by the media who condemned the Costa Rican artist for mistreating the animal. He, however, replied that the viewers reaction showed their hypocrisy: "If the dog had died on the street, no one would have noticed".

Other artists who exploit animals for their work are the artistic duo Sun Yuan and Peng Yu, with their 2017 Guggenheim Museum show Art and China after 1989 which featured taxidermy animals (Dogs That Cannot Touch Each

\footnotetext{
7 K. Tłuczek, Gdzie się kończy sztuka? - rozważania nad etycznym i estetycznym wymiarem sztuki wspótczesnej, „Civitas Hominibus: rocznik filozoficzno-społeczny” 2008, no 3, p. 155.

8 Ibid., p. 157.
} 
Other), and Adam Morrigan, who creates works from roadkill by framing their skin.

All the given examples were supposed to actively engage the audience. By generating shock, they were meant to point out important problems and the omnipresent hypocrisy of our world. When touching upon this subject, we must take an ethical perspective into account. The change in the status of animals in art also transforms the definition of art itself, expanding the spectrum of its possible media. The animal appears not only as a motif and subject, but its image goes beyond traditional decorative and symbolic functions. ${ }^{9}$ This kind of engaging artists is an issue going back to the 1970s. The French Collectif d'Art Sociologique, whose members drew on the work of sociologists such as Joseph Kosuth, declared that art is contextual. ${ }^{10}$ It serves as a definition, it does not exist in itself. According to them, art was to become a tool for contemplating culture. The object of an artist's endeavours are social issues, and art provides the means to analyze various cultural phenomena. The collective assumed that culture is based on communication and with that assumption they worked towards disrupting the channels of communication so that they could effectively influence the society.

The artists of today can be seen, in a truly nineteenth-century fashion, as secularized priests who, through the symbolic medium of ritual, attempt to reenact the intangible form of social relations in which the world is entangled. The problem is that they do not understand those relations which they want to express through art, nor does the society which is to be the recipient of that art. The given examples of controversial artworks cannot be contained by art or by the ethical dimension. Although the latter is often disputed as to whether it is relevant to art, the question can be posed as to why non-ethical whims and perversions are so often the material of contemporary art. While most definitions of art agree that one of its important functions is provocation and evoking an emotional response, it is unclear whether trespassing the boundaries of good taste and morality are necessary in addressing problems. Contemporary art reaches out to the audience through provocation, shock and irony in order to convey a message about the problems of the world. ${ }^{11}$ However, it should give rise to something more than just an intense emotional response. It should, primarily, provoke thought. Instead, the reception of an artwork is usually over as soon as it becomes a scandal, and any intended message goes unnoticed in the hubbub of protests and accusations. The art which triggers extraordinary

9 D. Gzyra, D. Łagodzka, op. cit., p. 6.

10 J. Kosuth, Sztuka po filozofii in: Zmierzch estetyki - rzekomy czy autentyczny?, ed. S. Morawski, Warszawa 1987.

11 K. Tłuczek, op. cit., p. 152. 
emotions is often based on permeating the existing understanding of art. It violates the dominating norms and values through the realization of a certain idea. Artworks bewilder through pervasiveness and suffering, but their meaning is often lost because the metaphor is hidden too deep. The practice of using animals in contemporary art may often seem absurd and insane. Would specifying the sphere of art protect it against those works which should not form part of its scope? Perhaps not-every attempt to frame art results in the limiting of artistic freedom. The whole problem with art is that we can only theorize about the extent of its field (its attributes, traits and determinants). However, the need arises to work out a general description of the concept, to at least sketch its frames, a point of reference which would serve as a tool for the evaluation of the growing vastness of emerging artworks and 'art-products'.

In observing the work of the artists of today it would seem that the boundaries of art have long been blurred and so contemplating the issue of overstepping its boundaries is redundant. On the other hand, however, there are examples of artworks which have caused scandals, shook up public opinion or sparked protests. That confirms that art can indeed overstep certain boundaries even if it impossible to define those boundaries precisely. There seems to be a line beyond which art becomes pseudo-artistic, but just what are the criteria which render some works art, and some definitely not art?

The definitions of the concept of 'art' are multiple and constantly multiplying. There does not seem to be any single definition which would fit every artwork. Each epoch produced its own definitions which were often stood in contradiction with one another. Then, the twentieth century brought two major breakthroughs. The 1920s saw the rise of such artistic movements as cubism, dadaism, futurism, surrealism, expressionism and fauvism. The 1960s and 1970s were the time of Jackson Pollock's abstract expressionism, Andy Warhol, conceptual art, happenings, or tendency zero (pol. tendencje zerowe), as termed by Jerzy Ludwiński, which are meant to mean artistic activity that deconstructs the understanding of what an artwork is. ${ }^{12}$

Contemporary art is characterized by the diversity of sensations it induces, varying from positive feelings and aesthetic enjoyment to states of anxiety, fear, anger or disgust. It is through shock, provocation or scandal that the artist reaches out to the audience. There are no taboo topics left-the limits of bodily pleasure, modesty, intimacy and shame, as well as cruelty and pain, have all been crossed. In all of this, the art-sphere, constantly in the progress of developing its language, seems to disregard the ethical dimension of its existence. An art which cannot be defined becomes something vague, blurred and ready

12 J. Ludwiński, Sztuka w epoce postartystycznej [in:] Idem, Epoka btękitu, Otwarta Pracownia, Kraków 2003, pp. 183-195. 
to accept anything into its midst. The governing aesthetic canon is obviously shifting, and art is taking on a new role, but many of the contemporary 'artistic' activities should never be considered art. While it stands as a fact that a principle characteristic of art is transgression of the functioning order, leaving the boundaryless leads to countless creations which self-proclaim themselves as art. According to Welsch, out of all the human forms of intellectual activity, it is art which is the most developed in questioning the orders set by philosophical, scientific or religious anthropocentrism. He notices that: "[...] the output of aesthetics beyond aesthetics towards a full range of aisthesis is necessary not only as a condition for a full understanding of aesthetics, but also as a condition for a sufficient understanding of art". ${ }^{13}$ And that is an advantage of art . With enthusiasm, but also with equally strong resistance, they reacted to the formulas: 'everything is art', 'art is life', 'every artist' (Joseph Beuys). As far as the crisis of the traditional understanding of art was concerned, "the crisis in relation to which aesthetics had to define itself", he prophetically, at the same time, aptly called Adorno by its name: "Aesthetics seems to imply tacitly the possibility of art in general, it sets itself on 'how' rather than on 'that' in advance. This kind of attitude has become uncertain. Aesthetics cannot continue to derive from the fact of art, just as Kantian theory of cognition used to derive from mathematical natural science. The fact that art, which insists on its definition and refuses to consume, turns into anti-art; its dissatisfaction with itself, after real catastrophes and in the face of future ones, whose further existence remains in a moral disproportion, all this is given to an aesthetic theory". ${ }^{14}$ Although it may seem absurd to impose boundaries on art when we have supposedly arrived at the stage when anything can be called art, it has become necessary to specify and clarify the vague concept of art, so that it can become a point of reference for the evaluation of artistic activity. This necessity arises not as much from the lack of aesthetic enjoyment in experiencing many of today's artworks, as from their neglection of an ethical dimension. ${ }^{15} \mathrm{We}$ are far from the times when the very gesture of publicly revealing an artwork caused excitement. The audience of today can only become agitated when an artwork goes beyond the boundaries of social conventions and expectations. Only then can an artist be said to have violated the orderly body of rules and laws.

The 1960s and 1970s were a time of searching for new ways to experience and understand art. The very concept of art was first questioned and then

13 W. Welsch, Estetyka poza estetyka. O nowa postać estetyki, tłum. K. Guczalska [in:] Idem, Estetyka poza estetyka. O nowa postać estetyki, ed. K. Wilkoszewska, Universitas, Kraków 2005, p. 144.

14 Th. W. Adorno, Teoria estetyczna, tłum. K. Krzemieniowa, PWN, Warszawa 1994, p. 617.

15 K. Tłuczek, op. cit., p. 151. 
established anew, after overturning the preceding methods of approaching and understanding it. This overthrowal proved revolutionary. The time had arrived to look at art as never before-its role for centuries had been to be beautiful or aesthetically pleasing; it was supposed to bring enjoyment, illustrate and reflect reality. As Grzegorz Dziamski points out: "For a long time the objective function of art was to bring about an aesthetic effect which could further serve to deepen the emotional effect of the values established by other forms of social activity such as religion, tradition, law, politics, etc. However, together with the growth and autonomization of artistic awareness, the conviction that the function of art was to bring about the aesthetic effect which was to validate the value systems of other social practices lost its absoluteness." 16

Art abandoned its visible value-experiencing it became a matter for the intellect. Its extra-visual values became more important than the viewership. The audience must consult the artist's vision in order to understand the artwork. Timothy Binkley points out that "from the outset aesthetics has been devoted to the study of things perceived whether reasoning from the aesthetic attitude which defines a unique way of perceiving, or from the aesthetic object of perception" ${ }^{17}$ Aesthetics had lost its point of reference. The revolution initiated by Duchamp overthrew the old order of understanding the history of art. Aesthetics, whose moment of perception was the most important point, has become useless in the face of the new concepts. Moreover, aesthetics considered the object of its study to be complete and finite. The artwork, however, turned out to be an object of multiple interpretations and understandings-it had become infinite. Its formerly passive audience became active and was forced to search for its own solutions to the problems posed. Finally, traditional aesthetics understood the artwork as an object. This has also lost its actuality-a work of art simply does not have to be an object. "Art in the twentieth century has emerged as a strongly self-critical discipline. It has freed itself of aesthetic parameters and sometimes creates directly with ideas unmediated by aesthetic qualities. An artwork is a piece; and a piece need not be an aesthetic object, or even an object at all". ${ }^{18}$

What caused the crisis of the established paradigm? It became apparent that art cannot be bound by any frames. Appeared subjective resistance, as Adorno notices: "Many people consider aesthetics unnecessary. They are disturbed by Sunday's pleasures, to which art has been reduced for them, an ad-

16 G. Dziamski, Szkice o nowej sztuce, Młodzieżowa Agencja Wydawnicza, Warszawa 1984, p. 42.

17 T. Binkley, Piece: Contra Aesthetics, „The Journal of Aesthetics and Art Criticism” 1977, Vol. 35, No. 3, p. 267.

18 Ibid. p. 265 . 
dition to bourgeois everyday life in their free time" ${ }^{19}$ The artwork disregarded everything that classified it as art. The goal was not to be aesthetically pleasing, and "the role of an artist as a craftsman of aesthetic objects was questioned." 20 Contemporary artwork does not only ignite the aesthetic sense, it also incites the intellect. Within this new state of affairs, the aesthetic paradigm had to either discard the faculty of taste or expand to its scope. Attempts to uncover new kinds of aesthetic value appeared. Maria Hussakowska-Szyszko claims that "aesthetics dispensed with the concept of beauty having recognized it as unstable. The principle concept became the concept of art. It was believed that its core could be reached through studying the process of perception. Aesthetic experience became an umbrella term. The non-identity of interpreter and artwork enabled to see art as a way of structuralizing material. The notion of material encompasses the personality of the artists, history, language, tradition, the explored topic, formal principles, ideology."21

Binkley saw in this the death of aesthetics without any need to reinstate it. The 'new' art is an entirely different stage which requires a new paradigm. Opposed to this view is Michael Kirby who probes for a new, extended definition of art. "The problem is clear: to provide a definition broad enough to include all that is considered art while clearly differentiating it from all that is not art". ${ }^{22}$ According to Kirby, an artwork can be experienced in a variety of ways, and every interpretation developed while experiencing it is correct. He argues that because of this the notion of aesthetics cannot be discarded, despite that fact that an artwork is not just a demonstration of the artist's technical skills or talent. The concept has to be modified to conform to the contemporary state of art. He is a forerunner of a different view on the relationship between art and audience in which the subjectivity of sensations conditioned by one's emotional state, cultural background and various other factors is recognized. Kirby is an advocate of retaining the concept of art, even if it means modifying it entirely, separating sharply with the earlier hermeticism of art. John Dewey wrote, "Esthetic experience is a manifestation, a record and celebration of the life of a civilization, a means of promoting its development, and is also the ultimate judgment upon the quality of a civilization." 23 All this leads towards the establishment of a novel type of relationship between artists and their audience; to a new type of aesthetic perception. With the greatest difficulty, a phenomenon

19 Th. W Adorno, op. cit., p. 612.

20 N. Tieng Hien, O znaczeniu śmierci sztuki in: Zmierzch estetyki rzekomy czy autentyczny?, vol. 2, Warszawa 1987, p. 7.

21 M. Hussakowska-Szyszko, Spadkobiercy Duchampa? Negacja sztuki w amerykańskim środowisku artystycznym, Kraków 1984, p. 11.

22 M. Kirby, The art of time. Essays on the avant-garde, New York 1969, p. 22.

23 J. Dewey, Art as Experience, New York 1980, p. 32. 
of open work has been created ${ }^{24}$-an unimaginable number of stances and thoughts are trying to systematize themselves, which might not be at all possible. Art is always a social fact, even when it is enclosed in a studio or gallery, speaking to a few people or even to itself. It has to keep its frames, because too much crossing of them makes it indistinguishable from the rest of reality. Definitions change the view, even if only general, and they order the reality. One has to bear in mind, however, that the example of art shows that for every premise and the resulting creative logic a specific awareness is needed, and that nothing would be falser - namely petty and trivial - than an assessment of every premise according to one measure and one set of criteria. ${ }^{25}$

\section{BIBLIOGRAPHY:}

Adorno Theodor W. (1994) Teoria estetyczna, transl. K. Krzemieniowa, Warszawa: PWN.

Baker Steve, The animal in contemporary art, http://www.fathom.com/feature/122562/index. html (08.03.2019).

Binkley Timothy (1977) Piece: Contra Aesthetics, "The Journal of Aesthetics and Art Criticism" Vol. 35 , No. 3

Dewey John (1980) Art as Experience, New York.

Dziamski Grzegorz (1984) Szkice o nowej sztuce, Warszawa: Młodzieżowa Agencja Wydawnicza.

Gzyra Dariusz, Łagodzka Dorota (2014) Uczestnicząc w zwrocie zwierzęcym. Sztuka wobec zwie$r z a t$, "Magazyn Sztuki" no 5.

Gzyra Dariusz (2014) Sztuka wspótczesna wobec etyki i dyskursu praw zwierzat, "Magazyn Sztuki” no 5.

Hussakowska-Szyszko Maria, (1984) Spadkobiercy Duchampa? Negacja sztuki w amerykańskim środowisku artystycznym, Kraków.

Kirby Michael (1969) The art of time. Essays on the avant-garde, New York.

Kosuth Joseph (1987) Sztuka po filozofii [in:] Zmierzch estetyki - rzekomy czy autentyczny?, ed. S. Morawski, Warszawa.

Ludwiński Jerzy (2003) Sztuka w epoce postartystycznej in: Idem, Epoka btękitu, Kraków: Otwarta Pracownia, pp. 183-195.

24 N. Tieng Hien, op. cit., p. 8.

25 W. Welsch, Narodziny filozofii postmodernistycznej z ducha sztuki modernistycznej, tłum. J. Balbierz [in:] Odkrywanie modernizmu. Przykłady i komentarze, ed. R. Nycz, Universitas, Kraków 1998, p. 460. 
Tieng Hien Ngo (1987) O znaczeniu śmierci sztuki in: Zmierzch estetyki rzekomy czy autentyczny?, vol. 2, Warszawa.

Tłuczek Katarzyna (2008) Gdzie się kończy sztuka? - rozważania nad etycznym i estetycznym wymiarem sztuki wspótczesnej, "Civitas Hominibus: rocznik filozoficzno-społeczny” no 3.

Welsch Wolfgang (2005) Estetyka poza estetyka. O nowa postać estetyki, tłum. K. Guczalska [in:] Idem, Estetyka poza estetyka. O nowa postać estetyki, ed. K. Wilkoszewska, Kraków: Universitas.

Welsch Wolfgang (1998) Narodziny filozofii postmodernistycznej z ducha sztuki modernistycznej, tłum. J. Balbierz [in:] Odkrywanie modernizmu. Przykłady i komentarze, ed. R. Nycz, Kraków: Universitas.

\section{PRZENIKANIE CZY PRZEKRACZANIE? O GRANICACH WE WSPÓŁCZESNEJ SZTUCE (streszczenie)}

Artykuł omawia znaczenie warstwy etycznej oraz granic we współczesnej sztuce. W tekście przywołane zostają dzieła, które powstały w wyniku torturowania bądź zabicia zwierząt. Prace te zostały uznane za przekraczające etyczne granice, wywołały oburzenie i liczne protesty publiczności. Omówione zostają konsekwencje tych reakcji oraz skandalu, jaki powstał wokół przywołanych prac, co zmusza do zadania pytania nie tylko o granice dzieła sztuki, znaczenie estetyki, ale również o definicję pojęcia „sztuka”, które poddawane wielu redefinicjom utrudnia, lub nawet uniemożliwia, ustanowienie czytelnych zasad. Analiza jest nie tylko próbą odpowiedzi na pytania o granice sztuki współczesnej, ale również o zasadność samego pojęcia „sztuka” wobec współczesnych działań artystycznych.

Słowa kluczowe: granice sztuki, sztuka współczesna, etyka, definicja sztuki, zwierzęta w sztuce, dzieło sztuki

Olga Jagnicka - MA, graduated from art history at the University of Łódź. Since 2016, postgraduate student in Humanities at the Faculty of Philosophy and History of the University of Łódź (Chair of Art History). Her scholarly interests include: art after the war, theory of art, modern theater. 